\title{
Critical review of cancer risk associated with angiotensin receptor blocker therapy
}

This article was published in the following Dove Press journal:

Vascular Health and Risk Management

9 December 201 I

Number of times this article has been viewed

\author{
Grégoire Wuerzner ${ }^{1,3}$ \\ Michel Burnier' \\ Bernard Waeber ${ }^{2,3}$ \\ 'Service of Nephrology and \\ Hypertension Consultation, Centre \\ Hospitalier Universitaire Vaudois, \\ ${ }^{2}$ Division of Clinical Pathophysiology, \\ Centre Hospitalier Universitaire \\ Vaudois, ${ }^{3}$ Clinical Research Centre, \\ Unil/Centre Hospitalier Universitaire \\ Vaudois, Lausanne, Switzerland
}

Correspondence: Bernard Waeber Division de Physiopathologie Clinique, Centre Hostpitalier Universitaire Vaudois, I0I I Lausanne, Switzerland

$\mathrm{Tel}+4 \mid$ 2। 3 | 4 | 43 3

Fax $+4 \mid$ 2। $3|4| 432$

Email bernard.waeber@chuv.ch

\begin{abstract}
The role of drugs in new cancer occurrence and cancer-related death is a major concern. Recently, a meta-analysis raised the possibility that angiotensin receptor blockers (ARBs) might have an adverse effect on patients. This generated a significant debate until the publication of two further meta-analyses, neither of which demonstrated an increased risk of new cancer occurrence or cancer-related death with the use of ARBs in patients with hypertension, heart failure, and/or nephropathy. This illustrates that the results of meta-analyses should be interpreted cautiously and critically as bias, such as selection bias, might lead to erroneous conclusions. Overall, the bulk of evidence today indicates that ARBs are not associated with increased cancer risk.
\end{abstract}

Keywords: hypertension, cancer, angiotensin receptor blocker, meta-analyses

\section{Introduction}

Hypertension and cancer are both major health issues worldwide. They have stimulated research into pharmacological products to decrease the burden associated with the diseases. However, hypertension and cancer are not perceived the same way, as the negative image of cancer far outweighs that of hypertension.

Whenever approval is sought for a new drug, regulators from medical agencies such as the US Food and Drug Administration and the European Medicines Agency are faced with the difficult task of evaluating the risk-benefit ratio. This involves, on one hand, quantifying efficacy endpoints from controlled clinical trials and, on the other hand, quantifying harms reported from clinical trials and other sources such as spontaneous adverse event reports. However, the principles and methodology for risk-benefit assessment are currently lacking and quantitative risk-benefit assessment is not expected to replace qualitative evaluation according to the European Medicines Agency, ${ }^{1}$ even if decision analysis is introduced. ${ }^{2}$ Importantly, drugs are assessed at the population level, but patients and health professionals often focus their consideration on the risks and benefits for individuals.

In the case of hypertension, the availability of oral antihypertensive drugs has, according to findings from large controlled trials, decreased cardiovascular mortality and morbidity compared with placebo. These findings have been confirmed in several meta-analyses. ${ }^{3-5}$ However, the safety of these drugs, with regard to cancer risk, has been questioned from the time they were first marketed. This has been the case for reserpine, ${ }^{6}$ diuretics, ${ }^{7,8}$ calcium channel blockers, ${ }^{9}$ and angiotensin-converting enzyme inhibitors. ${ }^{10}$ On each occasion, a debate, secondary to conflicting results, has followed the release of these publications, resulting in the generation of new reviews 
and meta-analyses. ${ }^{11-13}$ More recently, the question of cancer occurrence in conjunction with the use of angiotensin II receptor blockers (ARBs) has also been addressed.

\section{Meta-analyses of ARBs and cancer}

The first meta-analysis of the relationship between ARBs and cancer was released on June 14, 2010. ${ }^{14}$ It included nine controlled randomized trials: five trials, with data from 61,590 patients, assessing new cancer risk as a primary objective, ${ }^{15-19}$ and eight trials, with data from 93,515 patients, assessing the risk of cancer-related death ${ }^{15,17-23}$ as a secondary objective.

Follow-up was at least 1 year and the number of patients included had to be at least 100. Of the patients included in the primary analysis, $85.7 \%$ were taking telmisartan. The analysis showed that the risk ratio (RR) of new cancer in patients randomized to ARBs compared with patients randomized to placebo was 1.08 (95\% confidence interval [CI] 1.01-1.15). There was no significant difference in the risk of cancer death (RR 1.07, 95\% CI 0.97-1.18) between patients randomized to ARBs and those randomized to placebo. The authors concluded that ARBs were associated with a modestly increased risk of new cancer occurrence. The absolute increase risk of cancer over a 4-year period was $1.2 \%$, which had to be interpreted, according to authors, in the view of the estimated $41 \%$ lifetime cancer risk. Some limitations acknowledged were: the pooled results were taken from trials not designated to explore cancer outcomes as primary outcome measures, the adjudication of cancer diagnoses was not uniform among the included studies, the possibility of publication bias, and the absence of access to individual data. The authors encouraged further investigations of ARBs and cancer risk.

The second meta-analysis was released online in the same journal on November 30, 2010. ${ }^{24}$ The authors undertook a traditional direct-comparison meta-analysis, a multiplecomparison or network analysis, and trial sequential analyses. The primary objectives were cancer risk and cancer-related deaths with antihypertensive drugs. Follow-up had to be at least 1 year and at least 100 patients had to be included in the trials. Of the 70 randomized control trials $(324,168$ participants), 23 included ARBs. ${ }^{15-22,25-39}$ Of note, two of the trials (Valsartan Heart failure trial [Val-Heft] and Candesartan in Heart Failure Assessment of reduction in Mortality and Morbidity [CHARM]-added ${ }^{20,33}$ were considered as angiotensinconverting enzyme inhibitors (ACE-Is) plus ARB trials, because ARBs were given on top of ACE-Is. Therefore, 21 trials, enrolling more than 120,000 patients, were included in the meta-analyses on ARBs. The mean follow-up was 3.5 years and heterogeneity was low.
The results from the multiple-comparison meta-analyses showed that the risk of cancer for each individual antihypertensive agent did not differ significantly from placebo. In particular, there was no excessive risk of cancer with ARBs (odds ratio 1.01, 95\% CI 0.93-1.09). However, the combination of ACE-Is and ARBs was associated with increased cancer risk when compared with placebo (odds ratio 1.14, 95\% CI 1.02-1.28) in one model but not in other models (random effect models). No difference in risk of cancer-related death was observed between placebo and antihypertensive drugs. For ARBs, the death rate was $1.33 \%$ with no increased risk (odds ratio 1.00, 95\% CI 0.87-1.15). Based on trial sequential analysis, results suggested that there was no evidence of a $5 \%-10 \%$ relative-risk increase of cancer and cancer-related death with any individual class of antihypertensive drugs studies. Limitations acknowledged by authors included: lack of adjustment for drug dosage or compliance to the assigned treatment, possible outcome measure reporting bias, and multiple testing. Since medications were grouped in classes, increase in cancer risk with an individual drug could not be excluded. The authors also pointed out that antihypertensive drugs are usually prescribed for decades and that the mean follow-up was only 3.5 years. They concluded that a clinically significant increase in cancer risk or cancer-related death was not observed in their large comprehensive analysis.

Finally, a third meta-analysis from the ARB Trialists Collaboration was published in April 2011 in the Journal of Hypertension. ${ }^{40}$ It included 15 large parallel long-term double-blind clinical trials ${ }^{15-20,22,23,25,30,39,41-45}$ involving 138,769 participants. More than 500 participants had to be included and the mean follow-up had to be at least 12 months. The primary objective of the study was cancer incidence in ARB versus non-ARB control treatment. The average follow-up ranged from 23 to 60 months.

Overall cancer incidence was $6.16 \%$ in participants allocated ARBs versus $6.31 \%$ in those assigned non-ARB treatment (odds ratio 1.00 with $95 \%$ CI $0.95-1.04$ ). However, the test for heterogeneity was significant. In the secondary analysis, no excess of cancer was observed for each individual ARB (candesartan, irbesartan, losartan, valsartan, telmisartan). Data on cancer death were available in 13 trials. Death from cancer occurred in $1.85 \%$ of the patients randomized to ARBs and in $1.77 \%$ of the patients randomized to non-ARBs (odds ratio $1.03,95 \%$ CI $0.95-1.12$ ). The test for heterogeneity was not significant. No excess risk of cancer was observed with the combination of ACE-Is and ARBs. The main limitation acknowledged by authors was 
the relatively short duration of exposure to antihypertensive drugs. The authors concluded that, in patients with cardiovascular disease, heart failure, hypertension, and diabetes, there is no significant excess in cancer with the long-term use of the ARBs included in their analysis.

\section{Can some meta-analyses be misleading?}

Meta-analyses are often seen as the holy grail of evidence medicine, having the "strongest" level of evidence that can be obtained. However, they are and have been subject to criticism. ${ }^{46}$ Meta-analyses have been developed in an attempt to resolve conflicting results from trials addressing similar issues. Those who believe in the efficacy of a given intervention tend to use positive (significant) trials to defend a point of view, and explain negative trials by a lack of statistical power. Conversely, those who do not believe that a given intervention has any efficacy will use negative trials as proof of inefficacy and will argue that positive (significant) trials are the result of chance. To draw conclusion from conflicting results, data have to be synthesized and must take into account the possibility of underpowered negative trials and the possibility of a type I error (false positive) in positive trials.

The main advantages of a meta-analysis over a single trial or several trials taken individually are: to increase power, to reconcile apparently discordant results, to increase the accuracy of the size of the effect of treatment, to test and increase the extent of the result to a large number of patients, to explain the variability of the results, and, in some cases, to notice the lack of reliable data. Key elements of meta-analyses are that the synthesis is exhaustive, rigorous, reproducible, and quantifiable. Table 1 summarizes some questions to be asked when reading a meta-analysis.

In the case of ARBs, critical reading of the meta-analyses available is essential, particularly when different metaanalyses provide divergent results. The conflicting results obtained by the three meta-analyses discussed are probably best explained by the clinical trials selected for the analyses

Table I Some questions to be asked when reading a metaanalysis

Has the research of published trials been extensive?

Have unpublished trials been searched?

Have the trials been included independently of their results?

Have the reasons for exclusion of trials been specified?

Are the trials included in the analysis devoid of methodological flaws?

If heterogeneity was detected, has an explanation been sought?

Are the results of the analysis clinically relevant?

Can the analysis assess the benefit-risk balance?

Does the conclusion reflect the results of the analysis?
(Table 2), one of the most frequent reasons of discordance. Selection criteria and a time effect (new trials available) explain the different studies included in the meta-analyses.

Finally, the lack of evidence of a significant effect of ARBs on cancer incidence does not necessarily mean that there is no effect. This point is often raised in the concluding remarks of negative meta-analyses and was evident in the meta-analysis of Bangalore et al, ${ }^{24}$ in which the authors refuted a $5.0 \%-10.0 \%$ relative increase in the risk of cancer or cancer-related death with the use of ARBs.

\section{Is there a plausible pathophysiological mechanism explaining a causal relationship between ARBs and cancer?}

From a pathophysiological point of view, most of the evidence indicates that the inhibition of the renin angiotensin system is protective rather than deleterious with regard to the development of cancer. After the publication of a retrospective study suggesting lower than expected incidence of lung and breast cancer in hypertensive patients taking ACE-Is, ${ }^{47}$ possible pathophysiological mechanisms for such a finding were explored. ${ }^{48}$ So far, it has been shown that components of the renin angiotensin system are expressed in cancer cells from various tissues including the lungs, kidneys, breast, and prostate. ${ }^{49}$ Further, angiotensin II has been shown to have a local effect on cell proliferation, angiogenesis, and inflammation, in addition to its well-known systemic effects on the cardiovascular system. These local effects are mediated by the angiotensin II type 1 receptor or the angiotensin II type 2 receptor, which have different tissue distribution. They can, respectively, activate or inhibit various cascades of intracellular protein kinases usually associated with growth factors.

The main effect of ARBs on cancer appears to be through inhibition of the release of pro-angiogenic factors from tumor cells in vitro. ${ }^{50}$ This has been observed with candesartan in various cancer cell lines. ${ }^{51-53}$ Decrease in the expression of the vascular endothelial growth factor receptor 1 has also been observed. ${ }^{51,53,54}$ This effect could be mediated by an inhibitory effect of ARB on hypoxia-inducible-factor and ETS-1 induction, which has been reported in hormone refractory prostate cancer cell lines. ${ }^{55}$ Hence, these studies provide a molecular basis suggesting that ARB has a protective effect against some cancers. However, a few studies have shown that ARBs may increase vascular density in cancer models, an effect possibly mediated by the angiotensin type 2 receptor stimulation. ${ }^{56,57}$ In stroke models, ARBs 
Table 2 Trials included in the three meta-analyses

\begin{tabular}{|c|c|c|c|c|c|c|}
\hline Trial & ARB & $\mathbf{N}$ & Sipahi ${ }^{\mathrm{a}, 14}$ & Sipahi ${ }^{b, 14}$ & Bangalore $^{24}$ & ARB trialist ${ }^{40}$ \\
\hline LIFE $^{15}$ & Losartan & 9193 & $x$ & $x$ & $x$ & $x$ \\
\hline TROPHY'16 & Candesartan & 772 & $x$ & & $x$ & $x$ \\
\hline TRANSCEND $^{18}$ & Telmisartan & 5926 & $x$ & $x$ & $x$ & $x$ \\
\hline ONTARGET ${ }^{19}$ & Telmisartan & 25,620 & $x$ & $x$ & $x$ & $x$ \\
\hline PROFESS ${ }^{17}$ & Telmisartan & 20,332 & $x$ & $x$ & $x$ & $x$ \\
\hline CHARM overall ${ }^{23}$ & Candesartan & 7599 & & $x$ & $x^{*}$ & $x$ \\
\hline OPTIMAAL ${ }^{21}$ & Losartan & 5477 & & $x$ & $x$ & \\
\hline VALIANT 22 & Valsartan & 14,703 & & $x$ & $x$ & $x$ \\
\hline VAL-HEFT ${ }^{20}$ & Valsartan & 5010 & & $x$ & $x$ & $x$ \\
\hline i-PRESERVE ${ }^{39}$ & Irbesartan & 4128 & & & $x$ & $x$ \\
\hline ACTIVE-I ${ }^{42}$ & Irbesartan & 9016 & & & & $x$ \\
\hline IDNT $^{25}$ & Irbesartan & 1715 & & & $x$ & $x$ \\
\hline VALUE ${ }^{30}$ & Valsartan & 15,245 & & & $x$ & $x$ \\
\hline NAVIGATOR $^{4 I}$ & Valsartan & 9306 & & & & $x$ \\
\hline SCOPE ${ }^{16}$ & Candesartan & 4964 & & & & $x$ \\
\hline DIRECT $^{43,45}$ & Candesartan & 5231 & & & & $x$ \\
\hline ALPINE $^{32}$ & Candesartan & 393 & & & $x$ & \\
\hline $\mathrm{E}-\mathrm{COST}^{37}$ & Candesartan & 2048 & & & $x$ & \\
\hline GISSI-AF'7 & Valsartan & 1442 & & & $x$ & \\
\hline HIJ-CREAT ${ }^{31}$ & Candesartan & 2049 & & & $x$ & \\
\hline IRMA $2^{35}$ & Irbesartan & 608 & & & $x$ & \\
\hline JIKE| ${ }^{34}$ & Valsartan & 3081 & & & $x$ & \\
\hline KYOTO Heart study ${ }^{36}$ & Valsartan & 3031 & & & $x$ & \\
\hline RENAAL $^{26}$ & Losartan & 1513 & & & $x$ & \\
\hline $\operatorname{ROAD}^{29}$ & Losartan & 360 & & & $x$ & \\
\hline Suzuki et $\mathrm{a}^{38}$ & Valsartan, candesartan, losartan & 366 & & & $x$ & \\
\hline
\end{tabular}

Notes: *Only CHARM added ${ }^{33}$ and CHARM alternative. ${ }^{28}$ aAssessment of new cancer risk; bassessment of cancer-related death risk.

Abbreviation: ARB, angiotensin receptor blocker.

may play an angiogenic role. ${ }^{58,59}$ Therefore, the angiogenic effect of angiotensin II receptor blockade may conceivably be organ specific. More basic studies are needed to explain the potential role of ARBs in local cell proliferation and angiogenesis in more detail.

\section{Risk of cancer in hypertensive patients}

As previously mentioned, the potential cancer risk associated with antihypertensive drugs has been in question since these drugs first became available. One of the difficulties has been in the determination of the cancer risk associated with hypertension itself or to factors associated with hypertension, such as age, obesity, and blood pressurelowering drugs.

Several epidemiological prospective studies have shown that high blood pressure is associated with increased cancer risk $^{60}$ and cancer mortality. ${ }^{61-63}$ In the first of these prospective studies, which describes the association between blood pressure and cancer, Dyer et al observe that the increased risk of death from cancer was seen in both treated and untreated patients. ${ }^{62}$ Some have suggested that the causal direction is from cancer to hypertension, because the increased risk of malignancy is most pronounced among newly diagnosed hypertensive patients. ${ }^{60}$ However, uncertainties persist, mainly concerning the effect of the duration of the disease, age and sex of patients, and cancer-site specificity. ${ }^{64}$ For example, the effect of time is illustrated in a prospective study where a negative association between blood pressure and cancer during the first 5 years of follow-up changed into a positive association after 13 years of follow-up. ${ }^{65} \mathrm{Of}$ note, the mean follow-up of the these prospective epidemiological trials studying the association between hypertension and cancer ranged from 9 to 20 years, in comparison with a shorter follow-up, usually of less than 5 years, in the controlled studies included in the meta-analyses previously discussed. ${ }^{14,24,40}$

Obesity is another example of a risk factor associated with both cancer ${ }^{66}$ and hypertension. ${ }^{67}$ When the risk of renal cell carcinoma was studied in a Swedish cancer registry, both higher body mass index and elevated blood pressure were independently associated with long-term risk of renal cell cancer in men. ${ }^{68}$ This indicates that although obesity and hypertension are associated, they might influence renal cell cancer through different mechanisms. 


\section{Conclusion}

At a time when evidence-based medicine plays an increasing role in all fields of health care, meta-analyses have become an obligatory step in many areas of medicine. Their strength lies in compiling observations made in several trials, which provides increased power, secondary to the large number of participants included, to detect even small differences in outcomes. However, the selection or nonselection of trials within an analysis can strongly influence the results, as is illustrated in this review. For this reason, the search for trials has to be exhaustive and the selection criteria have to be well documented to avoid unrecognized selection bias ${ }^{69}$ Further, it has to be kept in mind that a population-level benefit observed in a metaanalysis does not necessarily apply to the individual patient.

The media buzz generated by the release of the first meta-analysis ${ }^{14}$ that observed an increased cancer risk with ARBs, currently some of the most prescribed cardiovascular drugs, has, however, prompted the scientific community to respond with new meta-analyses ${ }^{24,40}$ and the US Food and Drug Administration to release a statement ${ }^{70}$ concluding that the proven benefits of ARBs continue to outweigh their potential risk.

\section{Acknowledgment}

The authors thank Dr Narain Moorjani for critically reviewing the manuscript.

\section{Disclosure}

The authors report no conflicts of interest in this work.

\section{References}

1. Committee for Medicinal Products for Human Use, European Medicines Agency. Reflection Paper on Benefit-Risk Assessment Methods in the Context of the Evaluation of Marketing Authorization Applications of Medicinal Products for Human Use. London: European Medicines Agency; 2008. Available from: http://www.ema.europa.eu/docs/en_GB/ document_library/Regulatory_and_procedural_guideline/2010/01/ WC500069634.pdf. Accessed March 19, 2008.

2. Hughes DA, Bayoumi AM, Pirmohamed M. Current assessment of risk-benefit by regulators: is it time to introduce decision analyses? Clin Pharmacol Ther. 2007;82(2):123-127.

3. Turnbull F. Blood Pressure Lowering Treatment Trialists' Collaboration. Effects of different blood-pressure-lowering regimens on major cardiovascular events: results of prospectively-designed overviews of randomised trials. Lancet. 2003;362(9395):1527-1535.

4. Law MR, Morris JK, Wald NJ. Use of blood pressure lowering drugs in the prevention of cardiovascular disease: meta analysis of 147 randomised trials in the context of expectations from prospective epidemiological studies. BMJ. 2009;338:b1665.

5. Wright JM, Musini VM. First-line drugs for hypertension. Cochrane Database Syst Rev. 2009;3:CD001841.

6. Heinonen OP, Shapiro S, Tuominen L, Turunen MI. Reserpine use in relation to breast cancer. Lancet. 1974;2(7882):675-677.
7. Grossman E, Messerli FH, Goldbourt U. Does diuretic therapy increase the risk of renal cell carcinoma? Am J Cardiol. 1999;83(7): 1090-1093.

8. McLaughlin JK, Chow WH, Mandel JS, et al. International renal-cell cancer study. VIII. Role of diuretics, other anti-hypertensive medications and hypertension. Int J Cancer. 1995;63(2):216-221.

9. Pahor M, Guralnik JM, Ferrucci L, et al. Calcium-channel blockade and incidence of cancer in aged populations. Lancet. 1996;348(9026):493-497.

10. Effect of enalapril on mortality and the development of heart failure in asymptomatic patients with reduced left ventricular ejection fractions. The SOLVD Investigattors. N Engl J Med. 1992;327(10):685-691.

11. Coleman CI, Baker WL, Kluger J, White CM. Antihypertensive medication and their impact on cancer incidence: a mixed treatment comparison meta analysis of randomized controlled trials. J Hypertens. 2008;26(4):622-629.

12. Grossman E, Messerli FH. Long-term safety of antihypertensive therapy. Prog Cardiovasc Dis. 2006;49(1):16-25.

13. Grossman E, Messerli FH, Goldbourt U. Antihypertensive therapy and the risk of malignancies. Eur Heart J. 2001;22(15):1343-1352.

14. Sipahi I, Debanne SM, Rowland DY, Simon DI, Fang JC. Angiotensinreceptor blockade and risk of cancer: meta analysis of randomised controlled trials. Lancet Oncol. 2010;11(7):627-636.

15. Dahlöf B, Devereux RB, Kjeldsen SE, et al. Cardiovascular morbidity and mortality in the Losartan Intervention For Endpoint reduction in hypertension study (LIFE): a randomised trial against atenolol. Lancet. 2002;359(9311):995-1003.

16. Julius S, Nesbitt SD, Egan BM, et al. Feasibility of treating prehypertension with an angiotensin-receptor blocker. $N$ Engl J Med. 2006;354(16):1685-1697.

17. Yusuf S, Diener HC, Sacco RL, et al. Telmisartan to prevent recurrent stroke and cardiovascular events. $N$ Engl J Med. 2008;359(12): 1225-1237.

18. Telmisartan Randomised AssessmeNt Study in ACE iNtolerant subjects with cardiovascular Disease (TRANSCEND) Investigators; Yusuf S, Teo K, Anderson C, et al. Effects of the angiotensin-receptor blocker telmisartan on cardiovascular events in high-risk patients intolerant to angiotensin-converting enzyme inhibitors: a randomised controlled trial. Lancet. 2008;372(9644):1174-1183

19. Yusuf S, Teo KK, Pogue J, et al. Telmisartan, ramipril, or both in patients at high risk for vascular events. $N$ Engl J Med. 2008;358(15):1547-1559.

20. Cohn JN, Tognoni G. A randomized trial of the angiotensinreceptor blocker valsartan in chronic heart failure. $N$ Engl J Med. 2001;345(23):1667-1675.

21. Dickstein K, Kjekshus J. Effects of losartan and captopril on mortality and morbidity in high-risk patients after acute myocardial infarction: the OPTIMAAL randomised trial. Optimal Trial in Myocardial Infarction with Angiotensin II Antagonist Losartan. Lancet. 2002;360(9335):752-760.

22. Pfeffer MA, McMurray JJ, Velazquez EJ, et al. Valsartan, captopril, or both in myocardial infarction complicated by heart failure, left ventricular dysfunction, or both. N Engl J Med. 2003;349(20):1893-1906.

23. Pfeffer MA, Swedberg K, Granger CB, et al. Effects of candesartan on mortality and morbidity in patients with chronic heart failure: the CHARM-Overall programme. Lancet. 2003;362(9386):759-766.

24. Bangalore S, Kumar S, Kjeldsen SE, et al. Antihypertensive drugs and risk of cancer: network meta analyses and trial sequential analyses of 324,168 participants from randomised trials. Lancet Oncol. 2011;12(1):65-82.

25. Berl T, Hunsicker LG, Lewis JB, et al. Cardiovascular outcomes in the Irbesartan Diabetic Nephropathy Trial of patients with type 2 diabetes and overt nephropathy. Ann Intern Med. 2003;138(7):542-549.

26. Brenner BM, Cooper ME, de Zeeuw D, et al. Effects of losartan on renal and cardiovascular outcomes in patients with type 2 diabetes and nephropathy. N Engl J Med. 2001;345(12):861-869. 
27. Disertori M, Latini R, Barlera S, et al. Valsartan for prevention of recurrent atrial fibrillation. $N$ Engl J Med. 2009;360(16):1606-1617.

28. Granger CB, McMurray JJ, Yusuf S, et al. Effects of candesartan in patients with chronic heart failure and reduced left-ventricular systolic function intolerant to angiotensin-converting-enzyme inhibitors: the CHARM-Alternative trial. Lancet. 2003;362(9386):772-776.

29. Hou FF, Xie D, Zhang X, et al. Renoprotection of Optimal Antiproteinuric Doses (ROAD) Study: a randomized controlled study of benazepril and losartan in chronic renal insufficiency. J Am Soc Nephrol. 2007;18(6):1889-1898.

30. Julius S, Kjeldsen SE, Weber M, et al. Outcomes in hypertensive patients at high cardiovascular risk treated with regimens based on valsartan or amlodipine: the VALUE randomised trial. Lancet. 2004;363(9426):2022-2031.

31. Kasanuki H, Hagiwara N, Hosoda S, et al. Angiotensin II receptor blocker-based vs non-angiotensin II receptor blocker-based therapy in patients with angiographically documented coronary artery disease and hypertension: the Heart Institute of Japan Candesartan Randomized Trial for Evaluation in Coronary Artery Disease (HIJ-CREATE). Eur Heart J. 2009;30(10):1203-1212.

32. Lindholm LH, Persson M, Alaupovic P, Carlberg B, Svensson A, Samuelsson O. Metabolic outcome during 1 year in newly detected hypertensives: results of the Antihypertensive Treatment and Lipid Profile in a North of Sweden Efficacy Evaluation (ALPINE study). J Hypertens. 2003;21(8):1563-1574.

33. McMurray JJ, Ostergren J, Swedberg K, et al. Effects of candesartan in patients with chronic heart failure and reduced left-ventricular systolic function taking angiotensin-converting-enzyme inhibitors: the CHARM-Added trial. Lancet. 2003;362(9386):767-771.

34. Mochizuki S, Dahlof B, Shimizu M, et al. Valsartan in a Japanese population with hypertension and other cardiovascular disease (Jikei Heart Study): a randomised, open-label, blinded endpoint morbiditymortality study. Lancet. 2007;369(9571):1431-1439.

35. Parving HH, Lehnert H, Brochner-Mortensen J, Gomis R, Andersen S, Arner P. The effect of irbesartan on the development of diabetic nephropathy in patients with type 2 diabetes. $N$ Engl J Med. 2001;345(12):870-878.

36. Sawada T, Yamada H, Dahlof B, Matsubara H. Effects of valsartan on morbidity and mortality in uncontrolled hypertensive patients with high cardiovascular risks: KYOTO HEART Study. Eur Heart $J$. 2009;30(20):2461-2469.

37. Suzuki H, Kanno Y. Effects of candesartan on cardiovascular outcomes in Japanese hypertensive patients. Hypertens Res. 2005;28(4):307-314.

38. Suzuki H, Kanno Y, Sugahara S, et al. Effect of angiotensin receptor blockers on cardiovascular events in patients undergoing hemodialysis: an open-label randomized controlled trial. Am J Kidney Dis. 2008; 52(3):501-506.

39. Zile MR, Gaasch WH, Anand IS, et al. Mode of death in patients with heart failure and a preserved ejection fraction: results from the Irbesartan in Heart Failure With Preserved Ejection Fraction Study (I-Preserve) trial. Circulation. 2010;121(12):1393-1405.

40. Teo KK, Sleight P, Gao P, et al. Effects of telmisartan, irbesartan, valsartan, candesartan, and losartan on cancers in 15 trials enrolling 138,769 individuals. J Hypertens. 2011;29(4):623-635.

41. McMurray JJ, Holman RR, Rutten GEHM, Califf RM. Effect of Valsartan on the Incidence of Diabetes and Cardiovascular Events. $N$ Engl J Med. 2010;362(16):1477-1490.

42. Yusuf S, Healey JS, Pogue J, et al. Irbesartan in Patients with Atrial Fibrillation. N Engl J Med. 2011;364(10):928-938.

43. Chaturvedi N, Porta M, Klein R, et al. Effect of candesartan on prevention (DIRECT-Prevent 1) and progression (DIRECT-Protect 1) of retinopathy in type 1 diabetes: randomised, placebo-controlled trials. Lancet. 2008;372(9647):1394-1402.

44. Lithell H, Hansson L, Skoog I, et al. The Study on Cognition and Prognosis in the Elderly (SCOPE): principal results of a randomized double-blind intervention trial. J Hypertens. 2003;21(5):875-886.
45. Sjolie AK, Klein R, Porta M, et al. Effect of candesartan on progression and regression of retinopathy in type 2 diabetes (DIRECT-Protect 2): a randomised placebo-controlled trial. Lancet. 2008;372(9647):1385-1393.

46. Grossman E, Goldbourt U. Meta analyses of antihypertensive therapy: Are some of them misleading? Curr Hypertens Rep. 2001;3(5):381-386.

47. Lever AF, Hole DJ, Gillis CR, et al. Do inhibitors of angiotensinI-converting enzyme protect against risk of cancer? Lancet. 1998; 352(9123):179-184.

48. Rosenthal T, Gavras I. Angiotensin inhibition and malignancies: a review. J Hum Hypertens. 2009;23(10):623-635.

49. Deshayes F, Nahmias C. Angiotensin receptors: a new role in cancer? Trends Endocrinol Metab. 2005;16(7):293-299.

50. Willis LM, El-Remessy AB, Somanath PR, Deremer DL, Fagan SC. Angiotensin receptor blockers and angiogenesis: clinical and experimental evidence. Clin Sci (Lond). 2011;120(8):307-319.

51. Imai N, Hashimoto T, Kihara M, et al. Roles for host and tumor angiotensin II type 1 receptor in tumor growth and tumor-associated angiogenesis. Lab Invest. 2007;87(2):189-198.

52. Kosugi M, Miyajima A, Kikuchi E, Horiguchi Y, Murai M. Angiotensin II type 1 receptor antagonist candesartan as an angiogenic inhibitor in a xenograft model of bladder cancer. Clin Cancer Res. 2006; 12(9):2888-2893.

53. Kosaka T, Miyajima A, Takayama E, et al. Angiotensin II type 1 receptor antagonist as an angiogenic inhibitor in prostate cancer. Prostate. 2007;67(1):41-49.

54. Otake AH, Mattar AL, Freitas HC, et al. Inhibition of angiotensin II receptor 1 limits tumor-associated angiogenesis and attenuates growth of murine melanoma. Cancer Chemother Pharmacol. 2010;66(1): 79-87.

55. Kosaka T, Miyajima A, Shirotake S, et al. Ets-1 and hypoxia inducible factor-1alpha inhibition by angiotensin II type-1 receptor blockade in hormone-refractory prostate cancer. Prostate. 2010;70(2): 162-169.

56. Clere N, Corre I, Faure S, et al. Deficiency or blockade of angiotensin II type 2 receptor delays tumorigenesis by inhibiting malignant cell proliferation and angiogenesis. Int J Cancer. 2010;127(10): 2279-2291.

57. Walther T, Menrad A, Orzechowski HD, Siemeister G, Paul M, Schirner M. Differential regulation of in vivo angiogenesis by angiotensin II receptors. FASEB J. 2003;17(14):2061-2067.

58. Forder JP, Munzenmaier DH, Greene AS. Angiogenic protection from focal ischemia with angiotensin II type 1 receptor blockade in the rat. Am J Physiol Heart Circ Physiol. 2005;288(4):H1989-H1996.

59. Kozak A, Ergul A, El-Remessy AB, et al. Candesartan augments ischemia-induced proangiogenic state and results in sustained improvement after stroke. Stroke. 2009;40(5):1870-1876.

60. Buck C, Donner A. Cancer incidence in hypertensives. Cancer. 1987;59(7):1386-1390.

61. Raynor WJ Jr, Shekelle RB, Rossof AH, Maliza C, Paul O. High blood pressure and 17-year cancer mortality in the Western Electric Health Study. Am J Epidemiol. 1981;113(4):371-377.

62. Dyer AR, Stamler J, Berkson DM, Lindberg HA, Stevens E. High blood-pressure: a risk factor for cancer mortality? Lancet. 1975;1(7915):1051-1056.

63. Khaw KT, Barrett-Connor E. Systolic blood pressure and cancer mortality in an elderly population. Am J Epidemiol. 1984;120(4): 550-558.

64. Hamet P. Cancer and hypertension. An unresolved issue. Hypertension. 1996;28(3):321-324.

65. Wannamethee G, Shaper AG. Blood pressure and cancer in middle-aged British men. Int J Epidemiol. 1996;25(1):22-31.

66. Calle EE, Thun MJ. Obesity and cancer. Oncogene. 2004;23(38): $6365-6378$. 
67. Kannel WB, Brand N, Skinner JJ Jr, Dawber TR, McNamara PM. The relation of adiposity to blood pressure and development of hypertension. The Framingham study. Ann Int Med. 1967;67(1):48-59.

68. Chow WH, Gridley G, Fraumeni JF Jr, Jarvholm B. Obesity, hypertension, and the risk of kidney cancer in men. NEngl J Med. 2000;343(18): 1305-1311.

69. Swales JD. Meta analysis as a guide to clinical practice. J Hypertens Suppl. 1993;11(5):S59-S63.
70. US Food and Drug Administration(FDA). FDA drug safety communication: ongoing safety review of the angiotensin receptor blockers and cancer [web page on the Internet]. Rockville, MD: 2010 [updated February 6, 2011]. Available from: http://www.fda.gov/Drugs/DrugSafety/Post marketDrugSafetyInformationforPatientsand/ucm 218845.htm Accessed September 1, 2011.

\section{Publish your work in this journal}

Vascular Health and Risk Management is an international, peerreviewed journal of therapeutics and risk management, focusing on concise rapid reporting of clinical studies on the processes involved in the maintenance of vascular health; the monitoring, prevention and treatment of vascular disease and its sequelae; and the involvement of metabolic disorders, particularly diabetes. This journal is indexed on PubMed Central and MedLine. The manuscript management system is completely online and includes a very quick and fair peer-review system, which is all easy to use. Visit http://www.dovepress.com/ testimonials.php to read real quotes from published authors.

Submit your manuscript here: http://www.dovepress.com/vascular-health-and-risk-management-journal 